\title{
Exploring Political Brand Identity and Political Brand Image in Non-Party Contexts from a Multi-stakeholder Perspective
}

\author{
G. Armannsdottir ${ }^{\mathrm{a}}$, and C. Pich ${ }^{\mathrm{b}}$
}

${ }^{a}$ Nottingham Business School, Nottingham Trent University, Burton Street Nottingham, United Kingdom. ${ }^{b}$ Nottingham Business School, Nottingham Trent University, Burton Street Nottingham, United Kingdom.

\section{Introduction}

Understanding political brands is a pertinent concern for the British Crown Dependency of Guernsey. Guernsey is a Channel Island, part of the British Isles yet not a member of the European Union. In addition, Guernsey currently has a non-political party system and all thirtyeight Members of Parliament [otherwise known as Deputies] are independent figures. Further, deputies stand as individuals, and members often form informal alliances repeatedly referred to as collections of constantly changing coalitions of support or 'quasi-political parties' Guernsey is set to hold an island-wide referendum by March 2018 on the island's electoral process, moving from seven constituencies to one island-wide constituency. The Guernsey Government believe the 2018 referendum will impact the way Members of Parliament are elected and envisage the creation and introduction of 'political parties', or formal alliances in anticipation for the 2020 General Election. The creation and introduction of political parties [political brands] on Guernsey would be unprecedented to the current-historic political environment of a non-party system structured by independent, individual politicians. Further, it is unknown whether the creation and introduction of political 'party' brands would have the same appeal, benefits and success compared with independent 'individual' political brands. This presents a unique opportunity for the proposed piece of research, which will have an impact as to whether political parties [political party brands] are desired by Guernsey's elected representatives and Guernsey citizens-voters, and if so, how will new political parties be created and conceptualised. However, in order to address this we need to frame the study within the sub-discipline of political branding.

The application of commercial branding theory to politics is nothing new (O'Cass and Voola 2011; O'Shaughnessy and Baines 2009; Rutter et al. 2015). There is a shared understanding that political parties, pressure groups, politicians, candidates and campaigns can be conceptualised as 'brands' (Guzman and Sierra 2009; Needham and Smith 2015; Peng and Hackley 2009; Pich et al. 2016; Scammell 2015; Smith 2009). Further, the sub-discipline of political branding has become a 'critical' and 'priority' issue that warrants continued attention (Speed et al. 2015). The application of branding to politics has been described as the most appropriate way to understand the political 'product' and a mechanism to frame the deconstruction process to understand the political promise put forward by political actors (Scammell 2015). Political brands are complex, multi-layered entities which are often difficult to unbundle (Lees-Marshment 2009; Lock and Harris 1996; Phipps et al. 2010). Further, political brands are powerful tools used as a short-cut mechanism to deconstruct the rational and irrational elements of the political offering (Scammell 2015). This is reinforced with continued calls for future research to focus on generating deeper insight into how political brands are developed and understood particularly in new settings and contexts (Needham and Smith 2015; Nielsen 2016; Ormrod and Henneberg 2011; Pich and Dean 2015; Scammell 2015; Speed et al. 2015). Subsequently, the objectives of this study are to: 
- Investigate how current non-party political brands create, develop and communicate their brand identity from the perspective of elected representatives

- Explore how current non-party political brand image is understood from the perspective of Guernsey voters

- Ascertain whether elected representatives and Guernsey voters desire political 'party' brands for the 2020 General Election.

\section{Theoretical Background}

Political brands can be considered a trinity of elements including the party, leader and policy (Butler et al. 2011; Davies and Mian 2010; Pich and Dean 2015; Speed et al. 2015). The trinity of elements need to ensure clear identification and differentiation from political competitors (Ahmed et al. 2015; Nielsen 2016; O'Cass and Voola 2011; Smith 2008). In addition, effective political brands should be strong, appealing, trustworthy, offer resonance, act as a decision making driver which in turn will support strategy development and build awareness in the mind of voters-citizens (Ahmed et al. 2015; Baines and Harris 2011; O'Cass and Voola 2011). However, the existing literature has tended to focus on 'party' political systems and overlooked political brands from non-party political systems where all candidates and politicians are independent candidates and representatives. Nevertheless, what about other typologies of political brands like in non-party systems? In addition, the existing body of knowledge has not explained how political brands exist or develop without the 'party' element from the trinity. This proposition is supported the demand for more depth and understanding on political brands especially non-party 'individual' political brands [elected representatives] (French and Smith 2010; O’Cass and Voola 2011; Peng and Hackley 2009; Scammell 2015).

Despite the calls for more research in this area, there are a few studies that have investigated 'individual' political brands. More specifically, studies have focused on politicians or candidates from political 'parties' in terms of brand personality, equity, identity or image and often compared 'corporate' and 'individual' political brands (Cwalina and Falkowski 2014; De Landtsheer and De Vries 2015; Milewicz and Milewicz 2014; Smith and Spotswood 2013; Speed et al. 2015). For example, Smith and Spotswood (2013) comparatively considered the brand equity of the UK Liberal Democrat Party from a corporate and individual-local perspective. Smith and Spotwood (2013) highlighted that successful political brands whether corporate or local-individual) communicated clear expectations, focused values, believable promises to constituents, which is often easier at a local rather than national level. Further, Smith and Spotwood (2013) argued that successful corporate political brands would depend on consistency between corporate and local-individual political brands. However, the work by Smith and Spotswood (2013) was developed from speeches, articles and other discourse rather than from the personal perspective of internal stakeholders. Therefore, more depth and understanding from a multi-stakeholder perspective would reveal greater insight into the individual-local political brand particularly in non-party contexts.

Existing political branding research primarily adopts either an internal (Busby and Cronshaw 2015; Cwalina and Falkowski 2014; de Landtsheer and Vries 2015; Milewicz and Milewicz 2014; Smith and Spotswood 2013) or external perspective to frame studies (French and Smith 2010; Peng and Hackley 2009; Phipps et al. 2010). More specifically, research devoted to an internal 'brand identity' perspective directs its attention to the political party, candidate or politician. Brand identity can be conceptualised as the current intended projection formulated and communicated by the brand's creator with the aim of attempting to establish a desired identity in the mind of the consumer (de Chernatony 2007; Kapferer 2008). Further, brand 
identity can be seen as a useful approach to generate a deep understanding from an internal standpoint and capture the 'central ideas of a brand and how the brand communicates these ideas to stakeholders' (de Chernatony 2007:45; Ross and Harradine 2011; Saaksjarvi and Samiee 2011). In contrast, research focusing on an external 'brand image' perspective considers the political offering from a citizen-voter orientation (Needham and Smith 20015; Nielsen 2016; O'Cass 2001). Brand image can be considered as the current-immediate associations perceived and formulated in the mind of the consumer, which is often out of control of the brand's creator (Nandan 2005; Rekom et al. 2006). In addition, brand image is externally created, and manifested through unique associations and perceptions, experiences and expectations linked to physical and intangible elements of a brand (Bosch et al. 2006a; Nandan 2005). Therefore, future research should attempt to capture insight into how political brands develop and communicate identity and how political brands are understood from an internal [revealed by the politician] and external perspective [revealed by the voter] (Baines et al. 2014; Needham and Smith 2015; O'Cass and Voola 2011; Pich and Dean 2015). However, how can we actually comprehend current political brand identity and political brand image?

One study that explored an 'internal-relational orientation' of several individual political brands was the work by Pich and Dean (2015). Pich and Dean (2015) explored the internal brand identity of UK Conservative Party politicians prior the 2010 UK General Election with the support of Kapferer's brand identity prism (Kapferer 2008). Further, the work by Pich and Dean (2015) not only revealed the complex related yet distinct nature of individual political brands and their relationship with their 'corporate Conservative Party' political brand but also demonstrated the problematic nature of applying the brand identity prism in its original form to deconstruct the internal orientation of a political brand. Pich and Dean (2015) concluded with a revised framework known as the 'political brand identity network' and challenged future studies to consider this as a workable tool to understand individual political brands from an internal-relational perspective. However, Pich and Dean (2015) concluded that the 'political brand identity network' could also support the understanding of external brand image. Therefore, could the 'political brand identity network' aid the exploration of internal political brand identity and external political brand image of non-party political brands?

Responding to this gap in the body of knowledge, this research will explore the internal brand identity of an 'individual' political brand from the perspective of elected representatives and investigate the external brand image of non-party political brand from the perspective of Guernsey voters. In addition, this study will assess the operationalisation of the 'political brand identity network' put forward by Pich and Dean (2015). Further, responding to the challenge from Pich and Dean (2015), this study will assess the usability of the political brand identity network to understand non-party political brand identity and political brand image. This will address the limited development of 'appropriate models' and frameworks that can be used to assist political entities in understanding their offering and support strategy development (Nielsen 2015; O'Cass and Voola 2011; Ormrod 2011; Scammell 2015). Confusion and advancement can be addressed by building on existing research by assessing existing models and frameworks in comparison with new settings and contexts (Nielsen 2016; O'Cass 2001; O'Cass and Voola 2011; Ormrod and Henneberg 2011; Scammell 2015; Speed et al. 2015).

\section{Research Design}

As this study aims to explore non-party political brands from a multi-stakeholder perspective, a qualitative interpretivist approach is adopted (Creswell 2007; Welch et al. 2011). This is consistent with the calls across the political branding discipline for more exploratory empirical research (French and Smith 2010; O'Cass and Voola 2011; Peng and Hackley 2009; Scammell 
2015). This study will involve two stages. Stage one involves twenty-one semi-structured interviews with current elected Deputies. Deputies from across the eight districts of Guernsey namely; Vale, Vale-West, St Sampson, St Peter Port-North, St Peter Port-South, South East, West and Castel (www.gov.gg) have been selected. Interviews will last between 60-90 minutes and will be conducted by the researchers from March 2018-May 2018. Stage two involves twelve focus group discussions with Guernsey citizens-voters. Focus group discussions will be organised according to voter age group following the conventional approach adopted by research organisitions such as YOUGOV and IPSOS-MORI to explore political brand image. More specifically, this study will adopt purposive sampling framework and Guernsey citizens will be grouped from 18-24, 25-34, 35-44, 45-54, 55-64 and 65+ and each group will serve to frame each focus group discussion (Gillham 2005; Malhotra and Birks 2003). Focus group discussions will be conducted July-September 2018.

Pilot interviews and focus group discussions were conducted in October 2017 to assess the usability of the interview-focus group schedules and aided development-refinement (Gillham 2005). The 'political brand identity network' (Pich and Dean 2015) serves as a conceptual framework to provide some structure the interviews-focus group discussions and be incorporated into the interview-focus group schedules (Gillham 2005; Zikmund 2003).Transcripts from the semi-structured interviews and the focus group discussions will be thematically analysed with the support of Butler-Kisber's (2010) two-stage analytical approach.

\section{Findings}

The findings from stage one of the study will generate insight on how current non-party political brands create, develop and communicate their brand identity from the perspective of elected representatives. For example, the findings will highlight how non-party political brands create-develop communication strategies and tactics, the significance of individual political personality as a tool to provide differentiation and whether personal values are used to characterise the brands (Ahmed et al. 2015; Nielsen 2016; O'Cass and Voola 2011; Smith 2008). The findings from stage two of the study will reveal how current non-party political brand image is understood from the perspective of Guernsey voters. For example, the insights linked to political brand image will reveal consistencies and incoherencies with communicated identity and awareness of communication strategies-tactics, personality characteristics and personal-cultural values of Deputies (Pich and Dean 2015). Stage two will also reveal understanding as to whether Guernsey citizens-voters desire political 'party' brands. This will address the third objective of the study. This in turn will highlight the ideal conceptualised political brand for Guernsey developed from a multi-stakeholder perspective.

\section{Discussion}

This study will also reveal the relationships between current Deputies and constituents, personal-working relationships with stakeholders across government departments and understanding of attitudes and opinions of political issues such as the introduction of parties. This in turn will introduce first-hand accounts of current non-party political brand identities. In addition, this stage will reveal if the 'party' dimension is the only missing element from the triad and provide understanding of the relevance of the 'policy' and 'leader-politician' dimensions (Butler et al. 2011; Davies and Mian 2010; Pich and Dean 2015; Speed et al. 2015). Further, this study will provide understanding into the relationships between voters and Deputies and highlight the perceptions, associations and imagery Guernsey voters ascribe to 
non-party political brands (Bosch et al. 2006a; Nandan 2005). This research will also reveal understanding as to whether Guernsey citizens-voters desire political 'party' brands. This in turn could result in a reconceptualization of political brands, which extends the political brand triad (Butler et al. 2011; Davies and Mian 2010; Pich and Dean 2015; Speed et al. 2015). Further, a revised definition could be tailored to the unique setting of island communities and this could have implications to other jurisdictions with non-traditional political brands. Finally, the applied findings will address the challenge put forward by Pich and Dean (2015) to assess the usability of the 'brand identity network' as a mechanism to explore internal political brand identity and external political brand image. This will go some way in addressing the limited number of 'appropriate frameworks' than can be used to assist researchers to understand brands and develop strategies to address any inconsistencies or misalignment between communicated identity and understood image (Nielsen 2015; O'Cass and Voola 2011; Ormrod 2011; Scammell 2015; Speed et al. 2015).

\section{Conclusion}

Subsequently, this study will seek to understand how independent elected representatives currently create and develop political brand identity and explore how Guernsey voters understand political brand image of non-party brands. Further, the findings will highlight a contribution to practice. For example, this study will reveal implications of the introduction of political 'party' brands to the prospective of an island-wide voting environment from the perspective of internal [Deputies] and external [citizens-voters] stakeholders. This research will offer internal political stakeholders insight into the perceptions, attitudes and opinions of external citizens-voters in terms of prospective political 'party' brands, desired configuration of political 'party' brands and highlight whether political 'party' brands have a role to play in the reformed electoral process on Guernsey. Further, the findings will offer internal political stakeholders the opportunity to design, create and develop their political brands in line with the wants and needs of the electorate, which in turn should strengthen political engagement, maintain personal relationships between politicians-voters and allow for the establishment of a tailored approach to political brand management in non-traditional political environments. Further, the findings will have a direct impact on the debate as to how Guernsey's electoral process develops following the 2018 Island Wide Referendum and legislates prior the 2020 Guernsey General Election. The findings will also have implications beyond non-party systems of government for example it may offer existing party-systems of government practical methods and initiatives to strengthen voter engagement and develop stakeholder relationships across jurisdictions and constituencies.

This study will also contribute to academic theory. For example, the addressed objectives will offer the researchers an opportunity reconceptualise political brands particularly in nontraditional contexts based on deep insight from the perspectives of citizens-voters, which in turn will allow the sub-discipline of political branding to advance-develop as an area of study (Needham and Smith 20015; Nielsen 2016; O'Cass 2001; Pich et al. 2016; Scammel 2015). In addition, this study will address explicit calls for future research in this area by outlining how independent political brands exist or develop without the 'party' element from the trinity assess the applicability of the 'trinity' concept to new jurisdictions. Finally, this study will assess the applicability of the 'political brand identity network' (Pich and Dean 2015) as a tool to explore internal political brand identity and external political brand image of non-party political brands from a multi-stakeholder perspective. 


\section{References}

Ahmed, M.A., Lodhi, A.S. and Ahmad, Z., (2015). Political Brand Equity Model: The Integration of Political Brands in Voter Choice. Journal of Political Marketing, DOI: 10.1080/15377857.2015.1022629

Baines, P., Crawford, I., O'Shaughnessy, N., Worcester, R., and Mortimore, R., (2014). Positioning in political marketing: How semiotic analysis adds value to traditional survey approaches. Journal of Marketing Management, 30 (1-2), 172-200.

Baines, P. and Harris, P. (2011). Marketing in the 2010 British General Election: perspectives, prospect, and practice. Journal of Marketing Management, 27 (7-8), 647-655.

Bosch, J., Venter, E. Han, Y., and Boshoff, C., (2006a). The Impact of brand identity on the perceived brand image of a merged higher education institution: Part one. Management Dynamics, 15 (2), 10-30.

Butler, P., Collins, N. and Speed, R., (2011). The Europeanisation of the British political marketplace. Journal of Marketing Management, 27 (7-8), 675-690.

Butler-Kisber, L., (2010). Qualitative Inquiry: Thematic, Narrative and Arts-Informed Perspectives, London: Sage Publications Ltd.

Creswell, J.W. (2007), Qualitative Inquiry and Research Design, London: Sage Publications Ltd.

Davies, G., and Mian, T., (2010). The reputation of the party leader and the party being led. European Journal of Marketing, 44 (3/4), 331-350.

De Chernatony, L., (2007). From Brand Vision to Brand Evaluation. Oxford: ButterworthHeinemann.

French, A., and Smith, G., (2010). Measuring political brand equity: a consumer oriented approach. European Journal of Marketing, 44 (3/4), 460-477.

Gillham, B. (2005), Research Interviewing: the range of techniques, Berkshire England: Open University Press.

Kapferer, J. N., (2008). The New Strategic Brand Management: creating and sustaining brand equity long term. London: Kogan Page.

Koc-Michalska, K. and Lilleker, D. (2017). Digital Politics: Mobilisation, Engagement and Participation. Journal of Political Communication, 34:1, 1-5.

Lees-Marshment, J. (2009), Political Marketing: Principles and Applications, Abingdon Oxon: Routledge.

Malhotra, N. K. and Birks, D.F. (2003), Marketing Research: An Applied Approach, Essex: Pearson Education Ltd.

Nandan, S., (2005). An exploration of the brand identity-brand image linkage: A communications perspective, Journal of Brand Management, 12 (4), 264-278. 
Needham, C., and Smith, G., (2015). Introduction: Political Branding. Journal of Political Marketing, DOI:10.1080/15377857.2014.990828

Nielsen, S.W. (2016). Measuring Political Brands: An Art and a Science of Mapping the Mind. Journal of Political Marketing, 15 (1), 70-95

O'Cass, A., (2001). Political marketing - An investigation of the political marketing concept and political marketing orientation in Australian politics. European Journal of Marketing, 35 (9-10), 1003-1025

O'Cass, A., and Voola, R., (2011). Explications of political market orientation and political brand orientation using the resource-based view of the political party. Journal of Marketing Management, 27 (5-6), 627-645.

Ormrod, R. P., and Henneberg, C. M., (2011). Political market orientation and strategic party postures in Danish political parties. European Journal of Marketing, 45 (6), 852-881

Peng, N., and Hackley, C., (2009). Are Voters, Consumers? A qualitative exploration of the voter-consumer analogy in political marketing. Qualitative Market Research: An International Journal, 12 (2), 171-186.

Pich, C., and Dean, D., (2015). Qualitative projective techniques in political brand image research from the perspective of young adults. Qualitative Market Research: An International Journal, 18 (1), 1-36.

Pich, C., Dean, D. and P, Punjaisri., (2016). Political Brand Identity. An examination of the complexities of Conservative brand and internal market engagement during the $2010 \mathrm{UK}$ General Election campaign. Journal of Marketing Communications, DOI: $10.1080 / 13527266.2013 .864321$.

Rekom, J.V., Jacobs, G., Verlegh, P.W.J., and Podnar, K., (2006). Capturing the essence of a corporate brand personality: A Western brand in Eastern Europe. Journal of Brand Management, 14 (1/2), 114-124.

Ross, J., and Harradine, R., (2011). Fashion value brands: the relationship between identity and image. Journal of Fashion Marketing and Management, 15 (3), 306-325.

Rutter, R. N. Hanretty, C. and Lettice, F. (2015), Political Brands: Can Parties Be Distinguished by Their Online Brand Personality, Journal of Political Marketing, DOI: 10.1080/15377857.2015.1022631

Saaksjarvi, M., and Samiee, S., (2011). Relationships among Brand Identity, Brand Image and Brand Preference: Differences between Cyber and Extension and Retail Brands over Time. Journal of Interactive Marketing, 25, 169-177.

Scammell, M., (2015). Politics and Image: The Conceptual Value of Branding. Journal of Political Marketing, 14 (1-2), 7-18

Smith, G., (2008). Politically Significant Events and Their Effect on the Image of Political Parties. Journal of Political Marketing, 4 (2-3), 91-114

Smith, G. and Spotswood, F. (2015), 'The brand equity of the Liberal Democrats in the 2010 General Election: a national and local perspective'. Journal of Political Marketing, 12 (2-3), DOI: $10.1080 / 15377857.2013 .781478$. 
Speed, R., Butler, P. and Collins, N., (2015). Human branding in political marketing: Applying contemporary branding thoughts to political parties and their leaders. Journal of Political Marketing, 6 (3), 27-42.

Welch, C., Piekkari, R., Plakoyiannaki, E., and Paavilainen-Mantymaki, E., (2011). Theorising from case studies: Towards a pluralist future for international business research. Journal of International Business Studies, 42, 740-762.

Zikmund, W.G. (2003) Business Research Methods, USA: Thomson Learning South-Western.

WwW.gov.gg 